\title{
Attitudes of Students of Croatian Teacher Training Studies towards Music Courses and Self-evaluation of their Playing Skills
}

\author{
Jasna Šulentić Begić ${ }^{1}$, Amir Begić ${ }^{1}$, Tihana Škojo ${ }^{1}$ \\ ${ }^{1}$ Academy of Arts in Osijek, Croatia \\ Correspondence: Amir Begić, Academy of Arts in Osijek, Croatia.
}

Received: December 13, 2016

Accepted: December 27, 2016

Online Published: December 30, 2016

doi:10.11114/jets.v5i1.2068

URL: http://dx.doi.org/10.11114/jets.v5i1.2068

\begin{abstract}
This paper shows a research, which comprised of 152 students of teacher training studies from the Faculty of Educational in Osijek in the Republic of Croatia. The research was conducted during the academic year 2011/2012 and the main aim was to explore students' attitudes towards the musical courses and a self-evaluation of their own singing and playing skills. The majority of participants were females between twenty and twenty-four years of age. Survey results indicate that participants are generally indifferent towards the musical courses Music theory and Music. This matter should be credited with the fact that the courses, as such, are abstract to anyone who does not have a particular prior knowledge of music. Regarding the course playing, the participants showed more positive attitudes with respect to the courses Music theory and Music. We believe that the reason for it lies in the fact that the students who enrolled the mentioned course acquire the skills of playing i.e. a procedural knowledge of music, and experience the course itself as more useful for them. Self-evaluations of students' playing and singing skills show some insecurity when it comes to playing on their own, as well as their singing, and students show uncertainty regarding their own music teaching competence, respectively.
\end{abstract}

Keywords: teacher training studies, students' music teaching competences, primary education, attitudes, self-evaluation

\section{Introduction}

\subsection{The Primary Music Education in the Republic of Croatia}

The primary education in the Republic of Croatia is carried out according to the curriculum and syllabus, which is a part of the CNES (Croatian National Educational Standard), which entered into force in the school year 2006/2007. In the first three grades, a primary education teacher delivers compulsory subjects, as well as Music lessons. The fourth grade features Music lessons carried out by a teacher of Music or a subject (qualified) teacher of Music depending on the school setup. The weekly schedule of Music lessons is one lesson in all grades of elementary school and in primary education, as well. In the first three grades of elementary school, Music lessons feature the following educational areas: singing, listening to music, playing and musical creativity. Music lessons emphasize the open form, according to which listening to music is a central and, at the same time, compulsory activity of music lessons. The other remaining areas are chosen in accordance with capabilities and desires of pupils. The teaching area of singing develops a feeling of precise intonation and rhythm, a musical memory and self-confidence. Singing implicates a continuing song performing without obligatory text remembering. The task of song singing is mainly a singing as such but not (only) the learning of songs. Listening to music as a teaching area develops the ability of hearing concentration, specification of hearing (possibility to recognize sound and melodies of different voices and musical instruments), analysis of the listened part and establishes basic aesthetic criteria of music evaluation. The task of listening is not only to develop musical taste but also to introduce concrete musical works and pieces. The teaching area of playing develops the sense of rhythm, metre, precise coordination and cooperation. The task of playing an instrument is playing as such but not (only) learning of specific musical piece. The teaching area of musical creativity sharpens specific musical abilities (intonation, rhythm), develops sensibility for music, prompts imagination of musical expression and self-confidence while expressing new ideas (Elementary school curriculum and syllabus, 2006). Teachers should be enabled to perform all these activities i.e. teacher training studies should enable developing student competences teaching music.

Today, the Republic of Croatia has several faculties, which offer a possibility of education of teachers of primary 
education. Teacher Education Studies are located in Osijek (with a department in Slavonski Brod), Zagreb (with departments in Petrinja and Čakovec), Zadar (with a department in Gospić), Split, Rijeka and Pula. During the teacher education studies, students should acquire competences for carrying out and teaching all compulsory subjects, as well as competences for teaching music lessons. The research in this paper attempted to find out whether students actually acquire competences necessary for successful teaching of music, and what is their attitude toward attended musical courses. You can find more in our research review.

\subsection{Material Studied}

Novak (2014) noticed that researches which examined the musical lessons at teacher education studies, emphasize the unevenness of students' entry competences, their skills and motivation. The main obstacles to the development of students' confidence to teach music are lack of time for music teaching practice and class management problems (Bariseri, 2000). Teachers are not well trained during their initial training to teach music in primary schools and have no confidence in teaching music (Mills, 1991; Gifford, 1993; Jeanneret, 1997). According to Stunnel (2010), the notion of one's own competence for successful teaching of music is essential to primary education teachers. However, Ballantyne \& Packer (2004) consider that primary education teachers can teach music and feel comfortable during its performance, but they also believe that providing professional assistance to teachers of primary education is one of the requirements for their proper musical education. DeVries (2011) shares a similar point of view, which emphasizes that an amount of time dedicated to music lessons at the teacher education studies influences the fact, whether a primary education teacher will teach music or give it over to a qualified teacher of music. Based on his survey, Altun (2005) suggests that teacher education faculties should engage more in educating students in the field of music, because the majority of them never learn how to teach music lessons. Kane (2005) states that musical course programmes have to be based on practical musical knowledge and skills, which have to be adopted through methodological methods of musical lessons, which will be applied in classrooms in the future by teachers. Hanley (1993) believes that musical skills should be developed with students of primary education, and qualify them to connect the theory with practice, and train them accordingly for independent learning.

\section{Method}

This research comprised of 152 students of Teacher Education Studies (eighty second-year students and seventy-two third-year students) from the Faculty of Educational in Osijek in the Republic of Croatia, who passed the courses Music theory, Music, Playing I and Playing II. The research was conducted during the academic year 2011/2012. The main aim of this research was to examine the attitudes of students towards passed courses, and to review the self-evaluation of their own playing and singing skills. The hypothesis was that students who attended a musical school/playing course/choir would have more positive attitudes than students with no similar experiences. We have examined their attitudes towards passed courses and the self-evaluation of their own playing skills through survey questionnaires (1,2 and 3). The majority of participants were females between twenty and twenty-four years of age. The students were duly informed about the survey date, which was conducted each academic year on a separate date, outside of regular lessons. The second-year students have filled out the Questionnaires 1 and 2. We examined their attitudes towards the courses Music theory and Music from the first year of study. Those two questionnaires consist of eight questions each and contain open, closed and combined types of questions. The third-year students have filled out the Questionnaire 3. We examined their attitudes towards the course playing, and the self-evaluation of their own playing competence-skill after the completed courses Playing I on the second year and Playing II on the third year of study. The Questionnaire 3 consists of fourteen questions each and contains open, closed and combined types of questions. We analysed the questionnaires for answers which have proved to be essential for drawing conclusions. The first three questions from the questionnaires 1, 2 and 3 concerned the factual data about a student, i.e.

- whether she/he has attended a musical school and for how long

- which instrument has she/he played

- whether she/she has attended a playing course and for how long

- whether she/he sang in a choir and for how long

The number of students which attended a musical school or playing courses (students with prior musical experience PME) is relatively small. Thus, such students, together with students which attended a singing choir, were treated as one group, and the rest (students without prior musical experience - WPME) as the other group. The fourth question - what is your attitude towards the course - examined the students' attitudes towards completed courses in all questionnaires. The following answers were possible: I am very interested, I have no clear attitude towards the course and I am not interested. In order to check the differences of these two groups with respect to courses, we used the non-parametric chi-square. In the fifth question - how did you mostly feel in lessons - we wanted to find out how students felt in 
lessons considering the hypotheses that students, who have attended a musical school/playing course/choir, will have more positive attitudes than the remaining students. The list contained fourteen types of emotional states, and students were supposed to mark how they have experienced the lessons. Seven emotional states referred to pleasant emotions (curious, beautiful, grateful, happy, encouraged, excited, important), and seven referred to unpleasant emotions (sad, bored, worried, irritated, confused, scared, nervous). Their answers were coded in such manner that the marked emotions (I have experienced that) were coded as one (1), and the ones which were left unmarked, as zero (0) (I haven't experienced that). The results were calculated afterwards separately for pleasant and unpleasant emotions, whereby each participant received a total score for pleasant and unpleasant emotions. In order to check the differences between pleasant and unpleasant emotions, the Mann-Whitney U-Test was used.

\section{Results}

\subsection{Survey Questionnaire 1-Attitudes towards the Course Music Theory}

Table 1 displays the number of second-year students of the Teacher Education Studies in Osijek, which attended a musical school or playing course or were in a choir and those without similar experiences.

Table 1. Second-year students with prior musical experience (PME) and the ones without such experience (WPME)

\begin{tabular}{lll}
\hline $\mathrm{N}=80$ & $\mathrm{f}$ & $\%$ \\
\hline Music school & 1 & 1.25 \\
Music school and choir & 2 & 2.50 \\
Playing course & 3 & 3.75 \\
Playing course and choir & 3 & 3.75 \\
Choir & 37 & 46.25 \\
Total PME & 46 & 57.50 \\
Nothing from the list (WPME) & 34 & 42.50 \\
\hline
\end{tabular}

Table 2 shows the attitudes of students towards the course Music theory. As it can be seen, $\chi^{2}$ test, regarding the attitudes towards the course Music theory, has not proven to be statistically important $\left(\chi^{2}(2)=2.715, \mathrm{p}>0.05\right)$. The two groups show no differences in attitudes towards the course Music theory.

Table 2. Students' attitudes towards the course Music theory (Results of the $\chi^{2}$ test at two degrees of freedom)

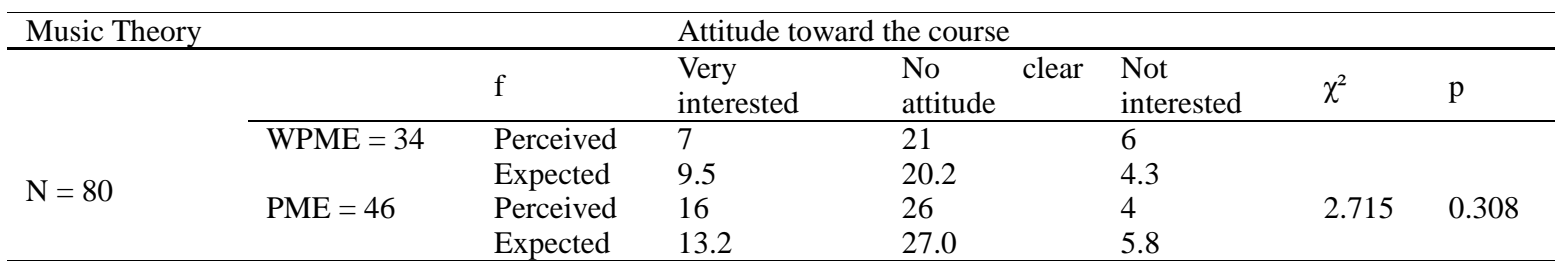

The results of answers to the fifth question - how did you mostly feel in lessons - are displayed in Table 3. The Mann-Whitney $U$-test $(\mathrm{U}=775.000, \mathrm{p}=0.943)$ shows that this aspect also shows no differences between students which attended some type of musical lessons from the remaining students. The students of both groups had the same emotional experience regarding the course. The fact that no differences have been found, does not imply that the hypotheses was groundless, on the contrary, it is based on the logics of music learning. The course Music theory, as it was defined within the teacher education studies, i.e. without a possibility of acquiring procedural musical skills, is essentially an abstract course for any student without particular prior musical knowledge of playing or solfeggio (which actually is a procedural knowledge of music). For this type of listeners, the course itself is incomprehensible and, logically, repulsive. The ground for not finding any differences in our research, according to our set hypotheses, lies in the fact that we had a small number of students - just nine- with relevant prior musical experience: musical school or playing course. The remaining students from the PME group had only had some choir experience which was apparently not enough to be considered as relevant. On the other hand, nine students with relevant music experience formed a tiny group, which made us unable to draw any valid conclusions. Thus, we are forced to give up on our hypotheses that students who attended a musical school/playing course/choir will have more positive attitudes when compared to other students, but not because we have proven its unsustainability, rather because the number of students from the group with prior musical experience (PME) was to small in order to consider their experience relevant. The results show - visible from the Table 2 and Table 3 - that the participants were mainly indifferent regarding to the course because the majority of them have no clear attitude towards it and there is an equal number of those with positive and negative attitudes. This fact referred to the fact that the course has been defined as a theoretical not practical course. The offered contents should fit the context where you can obtain not only declarative knowledge, but also procedural. 
Table 3. Pleasant and unpleasant emotions in Music theory lessons (Results of the Mann-Whitney U-test range sums)

\begin{tabular}{llllllll}
\hline Music Theory & & Pleasant emotions & \multicolumn{4}{c}{ Unpleasant emotions } \\
\hline & $\begin{array}{l}\text { Average } \\
\text { rank }\end{array}$ & $\begin{array}{l}\text { Mann-Wh } \\
\text { itney } \\
\text { U-test }\end{array}$ & $\mathrm{p}$ & $\begin{array}{l}\text { Average } \\
\text { rank }\end{array}$ & $\begin{array}{l}\text { Mann-Whi } \\
\text { tney } \\
\text { U-test }\end{array}$ & $\mathrm{p}$ \\
\hline $\mathrm{N}=80$ & $\mathrm{WPME}=34$ & 40.71 & 775.000 & 0.943 & $\frac{42.62}{38.93}$ & 710.000 & 0.446 \\
\cline { 2 - 6 }
\end{tabular}

\subsection{Survey Questionnaire 2-Attitude towards the Course Music}

Table 4 shows the attitude of students from the second year of Teacher Education Studies in Osijek towards the course Music. The $\chi^{2}$ test for testing the attitude towards the course Music is statistically very significant $\left(\chi^{2}(2)=7.063\right.$, $\mathrm{p}<0.05)$. Students who attended some of the mentioned activities have a more positive attitude towards the course Music than the remaining students.

Table 4. Students' attitudes towards the course Music (Results of the $\chi^{2}$ test at two degrees of freedom)

\begin{tabular}{|c|c|c|c|c|c|c|c|}
\hline \multirow[t]{2}{*}{ Music } & & & \multicolumn{5}{|c|}{ Attitude toward the course } \\
\hline & & f & $\begin{array}{l}\text { Very } \\
\text { interested }\end{array}$ & $\begin{array}{ll}\text { No clear } \\
\text { attitude }\end{array}$ & $\begin{array}{l}\text { Not } \\
\text { interested }\end{array}$ & $\chi^{2}$ & $\mathrm{p}$ \\
\hline \multirow{4}{*}{$\mathrm{N}=80$} & $\mathrm{WPME}=34$ & Perceived & 9 & 21 & 4 & \multirow{4}{*}{7.063} & \multirow{4}{*}{0.029} \\
\hline & & Expected & 12.3 & 20.0 & 1.7 & & \\
\hline & $\mathrm{PME}=46$ & Perceived & 20 & 26 & 0 & & \\
\hline & & Expected & 16.7 & 27.0 & 2.3 & & \\
\hline
\end{tabular}

The Mann-Whitney U-test was used to examine the differences in pleasant and unpleasant emotions that students have been experiencing in Music. The results are displayed in Table 5. There are no significant statistical differences in pleasant and unpleasant emotions of students with prior musical experience (PME) and those without such experiences (WPME) in the course Music. Although we found a statistically significant difference in the attitude towards the course Music, it will not be considered as an argument that our hypothesis was confirmed, namely, due to the same reason for not acting the same as with the course Music theory. Music is also a "theoretical" and verbal course without any possibility to gain procedural musical knowledge and is therefore, just like Music theory, abstract for anyone without certain musical background. Consequently, the statistically significant given fact should be assigned to some coincidental circumstances, rather than the actual difference between the two groups, mainly because we are talking about the same participants. There is no reason to believe that the abovementioned participants would have had a different attitude towards two very similar courses. Such thinking is reasonable and even more because concerning the pleasant and unpleasant emotional experiences, there are no differences between the groups. We will thus dismiss the thesis that students who attended a musical school/playing course/ choir will have more positive attitudes towards the course Music theory when compared to other students, but, once again, for the same statistical reasons we had earlier, in the first survey questionnaire - concerning the small number of participants with relevant and prior musical experience.

Table 5. Pleasant and unpleasant emotions in Music lessons (Results of the Mann-Whitney U-test range sums)

\begin{tabular}{llllllll}
\hline Music & & \multicolumn{3}{l}{ Pleasant emotions } & \multicolumn{3}{l}{ Unpleasant emotions } \\
\hline & $\begin{array}{l}\text { Average } \\
\text { rank }\end{array}$ & $\begin{array}{l}\text { Mann-Whi } \\
\text { tney } \\
\text { U-test }\end{array}$ & $\mathrm{p}$ & $\begin{array}{l}\text { Average } \\
\text { rank }\end{array}$ & $\begin{array}{l}\text { Mann-Wh } \\
\text { itney } \\
\text { U-test }\end{array}$ & $\mathrm{p}$ \\
\hline $\mathrm{N}=80$ & $\mathrm{PGI}=34$ & 35.54 & 613.500 & 0.083 & $\frac{43.82}{38.04}$ & 669.000 & 0.226
\end{tabular}

3.3 Survey Questionnaire 3-Attitude towards the Courses Playing I and II and Self-evaluation of One's Own Playing Competence

Table 6 displays the number of participants from the third year of the Teacher Education Studies in Osijek, who attended a musical school, playing course or choir singing, as opposed to the ones without similar experiences.

Table 6. Number of third-year students with prior musical experience (PME) and the ones without (WPME)

\begin{tabular}{lll}
\hline $\mathrm{N}=72$ & $\mathrm{f}$ & $\%$ \\
\hline Music school & 1 & 1.38 \\
Music school and playing course & 1 & 1.38 \\
Music school and choir & 2 & 2.77 \\
Playing course & 2 & 2.77 \\
Playing course and choir & 5 & 6.94 \\
Choir & 25 & 34.72 \\
Total PME & 36 & 50.00 \\
Nothing from the list (WPME) & 36 & 50.00 \\
\hline
\end{tabular}


Table 7 shows the attitude of students towards the courses Playing I and Playing II. The $\chi^{2}(3.471, \mathrm{p}>0.05)$ is here not significant either, which implies that even in that regard, there are no differences between students with prior musical experiences and the remaining ones. Considering the hypotheses that students with prior musical background will have more positive attitudes towards playing than students without similar experiences is psychologically and professionally acceptable - because it is logical to think that someone who is more successful will have a more positive attitude than the less successful ones - we will assign the fact for not finding any differences and not confirming our thesis to the same statistical grounds mentioned in the questionnaires 1 and 2: few participants with relevant prior musical experience, namely the prior experience of playing, in this case. Eleven of those participants were identified and shown in table 6, which was really not enough for drawing any conclusions.

Table 7. Students' attitudes towards the courses Playing I and Playing II (Results of the $\chi^{2}$ test at two degrees of freedom)

\begin{tabular}{|c|c|c|c|c|c|c|c|}
\hline \multicolumn{3}{|l|}{ Playing } & \multicolumn{5}{|c|}{ Attitude towards the course } \\
\hline & & $\mathrm{f}$ & Very interested & $\begin{array}{ll}\text { No } & \text { clear } \\
\text { attitude } & \\
\end{array}$ & $\begin{array}{l}\text { Not } \\
\text { interested }\end{array}$ & $\chi^{2}$ & $\mathrm{p}$ \\
\hline \multirow{4}{*}{$\mathrm{N}=72$} & WPME $=36$ & Perceived & 15 & 19 & 2 & \multirow{4}{*}{3.471} & \multirow{4}{*}{0.176} \\
\hline & & Expected & 18.0 & 17.0 & 1.0 & & \\
\hline & $\mathrm{PME}=36$ & Perceived & 21 & 15 & 0 & & \\
\hline & & Expected & 18.0 & 17.0 & 1.0 & & \\
\hline
\end{tabular}

The results of reviews of differences in pleasant and unpleasant emotions which students experienced in lessons of the course Playing I and Playing II are displayed in Table 8. The results of the Mann-Whitney U-test $(\mathrm{U}=399.000, \mathrm{p}<0.01)$ would imply that from students with prior musical experiences have reacted more positively towards the course Playing. No matter how essential this result may seem, together with the Mann-Whitney U-test speaking in favour, we will dismiss the hypotheses that the students with prior musical experience will have more positive attitudes towards the course Playing from students without similar experiences, due to statistical circumstances, i.e. a small number of participants from the RME group not allowing the thesis to be confirmed.

Table 8. Pleasant and unpleasant emotions in Playing I and Playing II lessons (Mann-Whitney U-test results range sums)

\begin{tabular}{|c|c|c|c|c|c|c|c|}
\hline \multicolumn{2}{|l|}{ Playing } & \multicolumn{3}{|c|}{ Pleasant emotions } & \multicolumn{3}{|c|}{ Unpleasant emotions } \\
\hline & & $\begin{array}{l}\text { Average } \\
\text { rank }\end{array}$ & $\begin{array}{l}\text { Mann- } \\
\text { Whitney } \\
\text { U-test }\end{array}$ & $\mathrm{p}$ & $\begin{array}{l}\text { Average } \\
\text { rank }\end{array}$ & $\begin{array}{l}\text { Mann-Whit } \\
\text { ney } \\
\text { U-test }\end{array}$ & $\mathrm{p}$ \\
\hline \multirow[t]{2}{*}{$\mathrm{N}=72$} & WPME $=36$ & 29.58 & \multirow{2}{*}{399.000} & \multirow{2}{*}{0.004} & 40.44 & \multirow{2}{*}{506.000} & \multirow{2}{*}{0.092} \\
\hline & $\mathrm{PME}=36$ & 43.42 & & & 32.56 & & \\
\hline
\end{tabular}

Students should answer the questions 8,9,10 and 11 by evaluating their playing skill, harmonization and singing competences.

8) How would you evaluate your playing skills? ( $1=$ bad $/ 5=$ excellent) (Circle the appropriate number) 12345

Table 9. Self-evaluation of the playing skill

\begin{tabular}{lllllll}
\hline Playing & \multicolumn{2}{l}{ RME $(\mathrm{N}=36)$} & \multicolumn{2}{l}{ WRME $(\mathrm{N}=36)$} & $\mathrm{N}=72$ & \\
\hline Grade & $\mathrm{f}$ & $\%$ & $\mathrm{f}$ & $\%$ & $\mathrm{f}$ & $\%$ \\
1 & 1 & 2.8 & 1 & 2.8 & 2 & 2.8 \\
2 & 7 & 19.4 & 15 & 41.7 & 22 & 30.6 \\
3 & 17 & 47.2 & 16 & 44.4 & 33 & 45.8 \\
4 & 10 & 27.8 & 4 & 11.1 & 14 & 19.4 \\
5 & 1 & 2.8 & 0 & 0.00 & 1 & 1.4 \\
Total & 36 & 100.0 & 36 & 100.0 & 72 & 100.0 \\
Average grade: & 2.86 & & & & & \\
\hline
\end{tabular}

The majority of students $(45.8 \%)$ evaluated their playing skill with the grade good. $30.6 \%$ of third-year students evaluated their playing skill as good and $19.4 \%$ as very good. Two students believe they have no playing skill at all, and one student evaluated his playing with the grade excellent. The self-evaluation grade average of the playing skill is good (2.86), which shows that third-year students believe they are averagely skilled at playing. They had completed three semesters of group lessons by the time of examination, namely, one lesson per week. Judging by the average grade, students evaluate their playing skill as good (Table 9). 
9) Can you independently come up with a song harmonization (accompaniment-chords)?
a) Yes (1 point)
b) No (0 points)

Table 10. Self-harmonizing of songs

\begin{tabular}{llcllll}
\hline Playing & \multicolumn{2}{l}{ RME $(\mathrm{N}=36)$} & \multicolumn{2}{l}{ WRME $(\mathrm{N}=36)$} & $\mathrm{N}=72$ & \\
\hline Grade & $\mathrm{f}$ & $\%$ & $\mathrm{f}$ & $\%$ & $\mathrm{f}$ & $\%$ \\
Yes & 4 & 11.1 & 0 & 0.00 & 4 & 5.6 \\
No & 32 & 88.9 & 36 & 100.0 & 68 & 94.4 \\
Total & 36 & 100.00 & 36 & 100.00 & 72 & 100.00 \\
\hline
\end{tabular}

Four third-year students stated they knew how to come up with chord accompaniment of songs, but it is more important to say that the majority of students - almost everyone - declared that they have no knowledge of that. It seems their evaluation was fair and honest (Table 19).

10) Do you sing the intonation accurately while accompanying yourself?

a) I have always problems with intonation (1 point)

b) I sometimes have problems with intonation. (2 points)

c) I sing the intonation accurately (3 points)

Table 11. Problems of singing and playing simultaneously

\begin{tabular}{lllllll}
\hline Playing & \multicolumn{2}{l}{ RME $(\mathrm{N}=36)$} & \multicolumn{2}{l}{ WRME $(\mathrm{N}=36)$} & $\mathrm{N}=72$ & \\
\hline Points & $\mathrm{f}$ & $\%$ & $\mathrm{f}$ & $\%$ & $\mathrm{f}$ & $\%$ \\
1 & 3 & 8.3 & 20 & 55.6 & 23 & 31.9 \\
2 & 21 & 58.3 & 15 & 41.7 & 36 & 50.0 \\
3 & 12 & 33.3 & 1 & 2.8 & 13 & 18.1 \\
Total & 36 & 100.0 & 36 & 100.0 & 72 & 100.0 \\
\hline
\end{tabular}

Even $81.9 \%$ of third-year students think they have certain problems with singing while playing on their own. The remaining $18.1 \%$ think they sing accurately. Once again, it seems that the participants were honest, realistic and that this is really true: the majority of students have minor or major issues with (school) singing (Table 11).

\section{Do you sing the intonation accurately without accompaniment?}

a) I always have problems with intonation (1 point)

b) I sometimes have problems with intonation (2 points)

c) I sing the intonation accurately (3 points)

Table 12. Problems of singing without accompaniment

\begin{tabular}{lllllll}
\hline Playing & \multicolumn{2}{l}{ RME $(\mathrm{N}=36)$} & \multicolumn{2}{l}{ WRME $(\mathrm{N}=36)$} & $\mathrm{N}=72$ & \\
\hline Points & $\mathrm{f}$ & $\%$ & $\mathrm{f}$ & $\%$ & $\mathrm{f}$ & $\%$ \\
1 & 3 & 8.3 & 21 & 58.3 & 24 & 33.3 \\
2 & 23 & 63.9 & 15 & 41.7 & 38 & 52.8 \\
3 & 10 & 27.8 & 36 & 100.0 & 10 & 13.9 \\
Total & 36 & 100.0 & 21 & 58.3 & 72 & 100.0 \\
\hline
\end{tabular}

Approximately the same or a slightly bigger number of students has problems with singing without their own accompaniment on an instrument (Table 12).

Students enrol the Teacher Education Studies in Osijek without taking the entrance examination and their musical capabilities are not tested, so there are some students with an undeveloped musical ear. Hence, it is not surprising that many students sing the intonation inaccurately. However, it is worrying, considering the fact that nice, clean and confident singing, as well as playing the accompanying instrument by a teacher, are basic prerequisites for implementation of students' singing activities.

\section{Discussion}

The research, which was conducted within this paper, showed us that the participants are mainly indifferent toward the courses Music theory and Music, because the majority has no clear attitude towards them, and there is an equal number of students with positive and negative attitudes towards them. This matter should be attributed to the fact that courses are defined as theoretical, meaning that you can only obtain declarative skills, but not procedural, and all the courses as such, are abstract to anyone without a particular musical pre-knowledge of solfeggio and playing. Declarative knowledge is completely useless to a teacher of primary education, not only because they are not required in the primary education musical lessons, but because such declarative knowledge does not enrich her/his musical competence. 
Participants have more positive attitudes regarding the course playing in comparison with the courses Music theory and Music. It can be explained by the fact that students, at the mentioned course, acquire the playing skill, i.e. procedural musical knowledge, and the course itself is then experienced as more useful. Self-evaluation of students' playing skills shows that they evaluate their playing as average. As for students' self-evaluation, in respect to intonation singing, merely $17.1 \%$ of third-year students think they sing the intonation accurately. Problems of singing without accompaniment are even more serious, because only $13 \%$ of students claim that they sing the intonation accurately without accompaniment. The results show that students have very low confidence in their own music teaching competence. They are very insecure with their own playing, as well as singing whether with or without an instrumental accompaniment. In other words, students have very little confidence in their own competence to teach music

So, how arrange courses of music lessons, so primary education students could acquire the necessary competences for music teaching? Namely, for future teachers, understanding of their own competence is very important for the successful teaching of music. Otherwise, they will be afraid of teaching music and they will try to avoid it (Hash, 2010; Stunell, 2010; Holden \& Button, 2006; Byo, 2000; Kempton, 1992). This is how we see the solution for acquiring the necessary competence and confidence! Firstly, for a successful performance of musical activities a teacher should, at least, display an average musicality - it is essential to memorize the melody, rhythm and reproduction accurately. Secondly, at the teacher education studies, learning music has to follow the path from practice to theory, i.e. in time-limited situations music has to be learned through the music itself, and it is also necessary to associate the key musical activities with corresponding methodical contents. Thirdly, musical competences of a primary education teacher cannot be specified differently, but in respect to the teaching curriculum of musical lessons in the first three grades of elementary school. This result in a fact that, during their education at the teacher training studies, teachers of primary education should be qualified for performing the following: singing and knowing songs, playing an instrument accompanying her/his own and pupil's singing, listening to music and being familiar with compositions, performing and knowing musical games and musical methodology. Learning music from practice to theory should make it possible.

\section{References}

Altun, Z. D. (2005). Exploring teaching strategies of Turkish primary teachers in music education (Doctoral dissertation). Retrieved from http://hdl.handle.net/2381/4718

Ballantyne, J., \& Packer, J. (2004). Effectiveness of pre-service music teacher education programs: Perceptions of early-career music teacher. Music Education Research, 6(3), 299-312. http://dx.doi.org/10.1080/1461380042000281749

Bariseri, N. (2000) Primary Music Teacher Education in England and Turkey (Doctoral dissertation). Retrieved from http://etheses.dur.ac.uk/4287/1/4287_1807.pdf?UkUDh:CyT

Byo, S. J. (2000). Classroom Teachers' and Music Specialists' Perceived Ability to Implement the National Standards for Music Education. Arts Education Policy Review, 101(5), 30-35. http://dx.doi.org/10.1080/10632910009600271

deVries, P. (2011). The first year of teaching in primary school: Where is the place of music? International Journal of Education \& the Arts, 12(2). http://www.ijea.org/v12n2/

Elementary school curriculum and syllabus (2006). Zagreb: Ministry of Science and Education of the Republic of Croatia.

Gifford, E. (1993). The Musical Training of Primary Teachers: Old Problems, New Insights and Possible Solutions. British Journal of Music Education, 10, 33-46. https://doi.org/10.1017/S0265051700001418

Hanley, B. (1993). Music teacher education: New directions. British Journal of Music Education, 10(1), 9-21. https://doi.org/10.1017/S026505170000139X

Hash, P. M. (2010). Pre-service Classroom Teachers' Attitudes toward Music in the Elementary Curriculum. Journal of Music Teacher Education, 19(2), 6-24. https://doi.org/10.1177/1057083709345632

Holden, H., \& Button, S. W. (2006). The teaching of music in the primary school by the non-music specialist. The British Journal of Music Education, 23(1), 23-38. http://dx.doi.org/10.1017/S0265051705006728

Jeanneret, N. (1997). Model for Developing Pre-service Primary Teachers' Confidence to Teach Music. Bulletin of the Council for Research in Music Education, 133, 37-44. http://www.jstor.org/stable/40318837

Kane, J. (2005). New ways of "training" in primary school music education: Results and implications of a longitudinal research study. Paper presented at the Australian Association For Research In Education Conference, Parramatta, NSW Australia. Paper retrieved from www.aare.edu.au/05pap/kan05133.pdf

Kempton, C. (1992). Developing music at key stage 2: A practical guide for non-specialist teachers in the primary 
school. Southgate Publishers.

Mills, J. (1991). Music in the Primary School (revised edition). Cambridge: Cambridge University Press.

Novak, M. (2014). Music Teaching Competences in Primary Education and Possibilities for their Further Advancement. In I. Prskalo, A. Jurčević Lozančić, Z. Braičić, Z. (Ed.), 14th Days of Mate Demarin Contemporary Challenges to Educational Theory and Practice (pp. 203-210). Zagreb, Croatia: University of Zagreb.

Saygi, C. (2010). Attitude scale development study in relation to music teaching Course. Procedia Social and Behavioral Sciences, 2, 5451-5457. https://doi.org/10.1016/j.sbspro.2010.03.889

Stunell, G. (2010). Not musical? Identity perceptions of generalist primary school theachers in relation to classroom music teaching in England. Action, Criticism, and Theory for Music Education, 9(2), 79-107. http://act.maydaygroup.org/articles/Stunell9_2.pdf

\section{Copyrights}

Copyright for this article is retained by the author(s), with first publication rights granted to the journal.

This is an open-access article distributed under the terms and conditions of the Creative Commons Attribution license which permits unrestricted use, distribution, and reproduction in any medium, provided the original work is properly cited. 